選択されるモジュールは 1 個であることから，並列共振 方式を採用した回転磁界駆動回路における 1 個の励振器 を共用し, チップヘ接続される電流供給回路とセンス回 路を共用するようにした. なお, 双方向移動は共振用二 ンデンサーの初期設定電圧の極性を励振器で変えること で実現した。

制御回路は情報の双方向移動を制御するとともに，と くに次のような装置制御をも可能にしているす?. 第 1 に, チップ内に欠楩のマイナーループが存在することを許容 するために，マイナーループのうちユーザーの利用しな い32ビット部分の 2 ビットに欠陷情報を書込んでいる. 電源投入後のイニシャライズ時にこの欠陥情報をIC RA $M$ に書込み, 以後, 通常の動作時には IC RAM の欠陥 情報に基づいて欠陥ループをマスクしている．第 2 に， 同じくイニシャライズ時に第 1 マイナーループの欠陥情 報を基準情報としてブロックアドレスカウンターを初期 設定し, 記憶位置とこの位置に存在する情報の持つアド レスとの対応を保持するようにしている。

\section{(4) 試験結果}

エキササイザーによって，書込みデータパターン，ア ドレス範囲, 読取り/書込み, 試験回数, などを指定して 高速バブルメモリー装置の試験を行ない，エラー情報を 収集した，試験では装置内で情報が双方向に移動するよ らなアドレスを順次与えた。標準試験条件での長時間試 験によりエラーレートは $10^{-9}$ 以下であること, 周囲温度 と電源電圧を変動して試験を行ない，表 4 の仕様が充分 満足されていることを確認した.

\section{§5. あとがき}

双方向移動による高速化に重点をおいて高速バブルメ モリー装置を紹介した. 対称パターンであるYYパター ンによるチップを使用すれば，この高速化の方法は周辺 回路の増加をほとんど伴わないで実現できるので有効な 方法である.

終りに, ご指導, ご助言をいただいた古尾谷部長はじ め関倸各位に感謝する.

なお本研究開発の一部は通商産業省工業技術院の大型 プロジェクト「パターン情報処理システムの研究開発」 の一環として行なわれたものである.

\section{〔参 考 文 献〕}

1）高橋, 小原, 村上：信学技報, $77,143, \mathrm{CPM}$ 77-70 (1977).

2) K. Yoshimi, N. Yoshioka, H. Urai, A. Morimoto and Y. Wada: JAP, 49, 3, Part II, 1918 (1978).

3）大表：信学技報, 75, 42, EC 75-17 (1975).

4) 吉広：信学技報, 76, 169, EC 76-57 (1976).

5) 山田, 村上, 大野：昭51信学会総合全大， 1346 (1976).

6) T. T. Chen and T. L. Chang: International Computer Symposium (1977).

7) 浦井, 吉見, 森本, 吉岡 : 第 1 回日本応用磁気 学会学術講演論文集 IaA-3 (1977).

8) 小原, 高橋, 村上：昭53信学会 総合全大, 247 (1978).

9) 山田, 永井, 高橋: 昭53信学会総合全大, 1548 (1978).

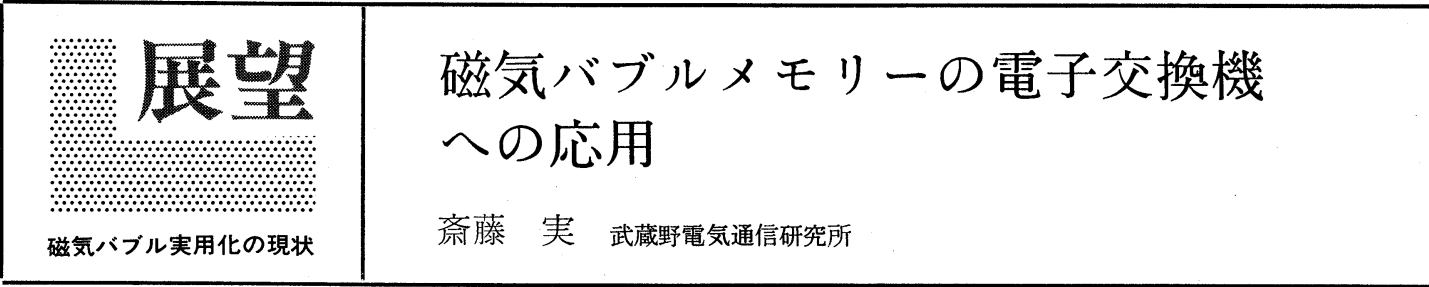

\section{§1. まえがき}

磁気バルブメモリーの技術開発は目ざましい発展を見 せており, 従来のデバイス面での発表に加え, 最近は装 置の実用化も行なわれている. 本格的な実用例として は, 電々公社が大容量可搬形電話局装置 (KD 20) の補 助記憶装置にバブルメモリーを使用した例があり ${ }^{1)}$ ， 国

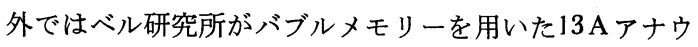

ンスメントシステムを従来のカセットの代替品として使 用した例が公表されているだけである2). しかし, 最近， 電々公社は64Mビットバブルメモリー装置を試作し, 大 局用電子交換機 (D10) の高速中央処理系装置 (D 10 HCP）に適用することを考えている ${ }^{3)}$.

これらの応用例では $3 \sim 5 \mu \mathrm{m}$ 径のバブルを用いた

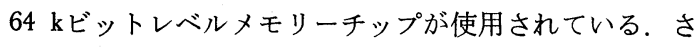
らにバブルメモリーの経済化をはかるためチップの高集 
積化 ${ }^{4}{ }^{6)}$ ，性能向上のための高速化 ${ }^{7)}$ も研究されてい る.

§. ニーズと適用上の問題

電々公社が使用する電子交換機においては, バブルメ モリーの用途は補助記憶装置で，これには現在は磁気ド ラムが使われている，磁気ドラムをバブルメモリーで置 き換える場合, バブルメモリーは磁気ドラムより低価格 であることは勿論, 同等以上の性能を有することが要求 される，その他にもソフトウェアを継承できること，保 守, 運用が簡単になることなどへの置換条件を満足する ことが要求される。

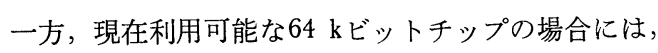
チップの駆動周波数（回転磁界の回 転 周 波数）は 100 $\mathrm{kHz}$ 程度である. メイジャー/マイナーループ構成では $100 \mathrm{kHz}$ 駆動で平均アクセスタイムは $5 \mathrm{~ms}$ が実現し, 従 来の磁気ドラム（平均アクセスタイム：10 ms）に比べ て高速である。しかし, 磁気ドラムのデータ転送速度 $1.7 \mathrm{Mbit} / \mathrm{s}$ (パリティービットを含む) を実現するには 数十チップを並列駆動する必要がある.

\section{$\S 3 . \quad \mathrm{K} \mathrm{D} 20$ 用 $12 \mathrm{M}$ ビット装置}

KD 20は中小局用電子交換機（D20）を基本にして設 計された可搬形電子交換機（1 万端子収容可能）で, D20の磁気ドラムに代えて輸送に便利な固体メモリーで あるバブルメモリーが使用された. このバブルメモリー は前述の置換条件を満たすため, 中央処理系装置とのイ ンターフェースでD20用磁気ドラムと完全互換がとれて いる.

このバブルメモリー装置の構成概要を図 1 に示す. 1 装置当り2.2Mビットのメモリーユニットが 6 個実装さ れている.このユニットの概要を表 1 に示す. また, 使

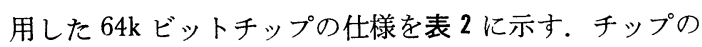
マイナーループは 4 個の予備ループを持っている. ユニ ットには 1 個のメモリーモジュールとその周辺電子回路 が実装されている.

モジュールのバイアス磁気回路の基本構成は図 2 に示 すように，2組のバイアス磁気回路が背中合わせに結合 したものである ${ }^{8}$. この構成は, バイアス磁石の動作パ 一ミアンスを大きくとれ, 経時変化に強く, 実装密度が 高く, バイアス磁石の微調が容易で, 外乱磁界の影響を 受けにくいなどの特長を有する．バイアス磁石およびョ ーク板はフェライトである. 1 組のバイアス磁気回路に は 1 組の駆動コイルが実装される。駆動コイルには10個 の64 kビットチップを搭載したメモリープレーンが 2 枚

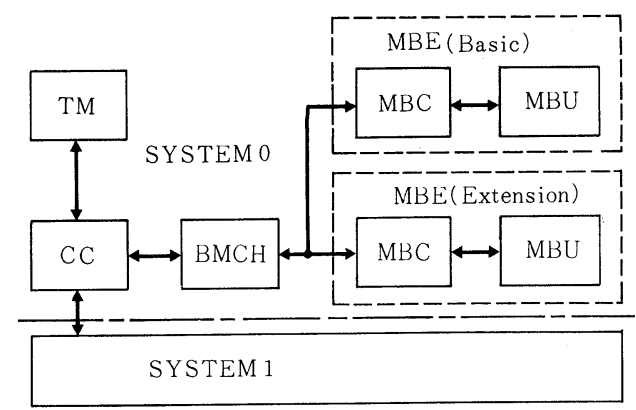

$\mathrm{TM}$ ：一時記憶装置 MBE：磁気バブル記憶装置 $\mathrm{C} \mathrm{C}$ ：中央処理装置 $\mathrm{MBC}:$ 磁気バブル制御装置 $\mathrm{BMCH}$ : チャネル装置 MBU : 磁気バブルメモリーユニット

図 1 K D20中央処理系装置の構成.

表 1 KD 20用メモリーユニットの概要.

\begin{tabular}{|c|c|}
\hline 諸 & 内 \\
\hline チ ッ プ & 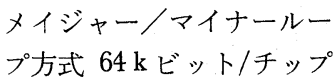 \\
\hline $\begin{array}{l}\text { 記 憶 容 量 } \\
\text { 平均アクセスタイム }\end{array}$ & $\begin{array}{l}\text { 2. } 2 \mathrm{M} \text { ビット } \\
5 \mathrm{~ms}\end{array}$ \\
\hline サイクルタイム & $10 \mathrm{~ms}$ \\
\hline 駆 動 周 波 数 & $100 \mathrm{kHz}$ \\
\hline インタフェース信号レベル & $\mathrm{TTL}$ \\
\hline 消 費 電 力 & $19 \mu \mathrm{W} /$ ビット \\
\hline 重量 & $7.6 \mathrm{~kg}$ \\
\hline 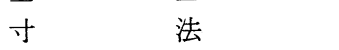 & $191^{\mathrm{H}} \times 135^{\mathrm{W}} \times 300^{\mathrm{D}} \mathrm{mm}$ \\
\hline
\end{tabular}

表 $264 \mathrm{k}$ ビットチップの仕様.

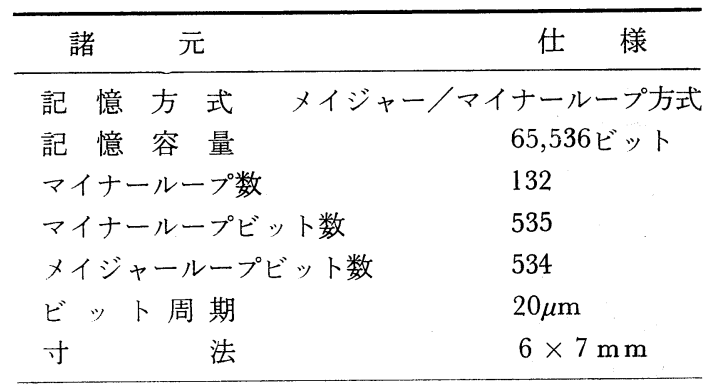

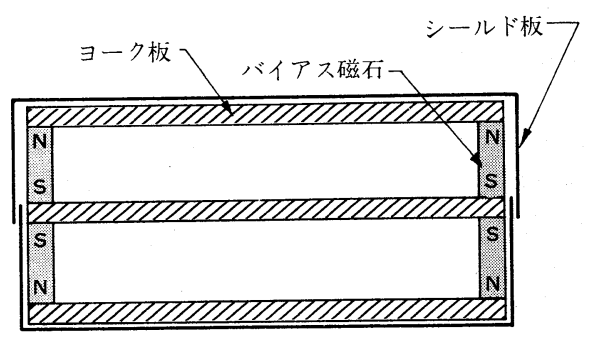

図 2 バイアス磁気回路の基本構成.

日本応用磁気学会誌 


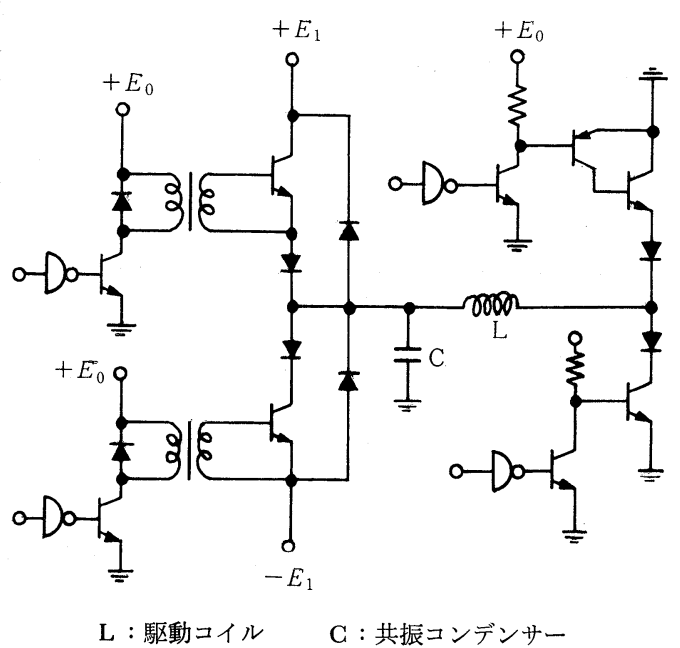

図 3 コイル騒動回路.

収容される、コイルの容積は約 $8 \mathrm{~cm}^{3}$ で，Qは14 16 $(100 \mathrm{kHz})$ である. メモリープレーン上のチップは 5 個

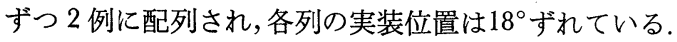

チップはパッシベーションのため, メモリープレーンと 同一材質のセミラックの蓋で封止され，窒素ガス雾囲気 中に置かれている. メモリープレーン上の10チップは 1 または 2 チップの予備チップを含んでいる.

コイル駆動回路は動作の安定な LC 並列共振回路(夕 ンク回路)で，駆動周波数の $1 / 4$ のクロックで電圧パルス により励振される ${ }^{9)}$. 回路の基本形を図 3 に示す. セン ス回路は 2 チップに対して 1 回路用意されており，チッ プの選択は検出器に流す検出器電流の切り換えにより行 なわれる. チップ上の 2 個の検出器の出力は差動増幅 後, さらに増幅され, 直流再生される. この場合, 1 個 のチップからの読出し速度は 1 ビット $/ 20 \mu \mathrm{s}$ である。 し かし，1.7Mビット/s のデータ転送速度を得るには 34 ビ ット $/ 20 \mu \mathrm{s}$ の割合で読み出す必要があるので, ビットはめ 込み法と時分割読出し法の 2 方法が用いられている ${ }^{11}$. なお, KD 20では, チップのマイナーループに欠陥があ っても，14ループ/ 4 チップの割合で予備のマイナール ープに切り換えるようにし，しかも論理的に切り換え制 御を行なっている.

§4. 大局用バブルメモリ一装置

大局用装置の規模は最小で512k語 ( 1 語 : $32+1$ パリ ティービット), 最大で2048k語であり, 増設単位は $256 \mathrm{k}$ 語である.これに使用するメモリーユニットの概要を表

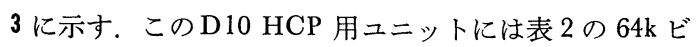
ットチップが使用されている. D10 HCP 用ュニットは
表 34 Mビットメモリーユニットの概要.

\begin{tabular}{|c|c|}
\hline 諸 & 容 \\
\hline 記 憶 容 量 & $4 \mathrm{M}$ ビット (4, 194, 304ビット) \\
\hline 使用チッ プ & $64 \mathrm{k}$ ビットチップ \\
\hline チップ実装数 & $80 チ ッ フ ゚$ \\
\hline 駆 動 周 波 数 & $100 \mathrm{kHz}$ \\
\hline 平均アクセスタイム & $\begin{array}{l}5.2 \mathrm{~ms} \text { (読出し), } \\
6.5 \mathrm{~ms} \text { (書込み) }\end{array}$ \\
\hline データ転送速度 & $200 \mathrm{k}$ バイト $/ \mathrm{s}$ \\
\hline インターフェース & TTL \\
\hline 電 源 電 圧 & $+5 \mathrm{~V},-5 \mathrm{~V},+12 \mathrm{~V},+40 \mathrm{~V}$ \\
\hline 消 費 電 力 & $\begin{array}{l}52.5 \mathrm{~W} \text { (最大), } \\
23.1 \mathrm{~W} \text { (スタンバイ) }\end{array}$ \\
\hline 寸 & $194^{\mathrm{H}} \times 133^{\mathrm{W}} \times 299 \mathrm{D} \mathrm{mm}$ \\
\hline 重 & $8 \mathrm{~kg}$ \\
\hline
\end{tabular}

KD 20用ユニットを基本にして設計されたものである が，周辺電子回路の IC 化や実装法の改良などにより， KD 20用ユニットと同じ大きさで 2 倍のメモリー容量と なっている. この大局用装置は今後の新設電子交換局に 採用されるものと思われる ${ }^{1,10)}$.

\section{$\S 5$. むす び}

電子交換機用バブルメモリーは，メモリー容量が大き く, かつ需要も多い. また, バブルメモリーの価格は生 産量に依存している. したがって, 今後, 電子交換機に バブルメモリーが全面的に採用されると, バブルメリモ 一の価格低減が進み, 他の応用分野でのニーズを換起す るものと考えられる. しかし，競合メモリーに対抗して バブルメモリーの適用領域の拡大をはかるには,さらに 低価格化と高速化の努力が必要となろう.

\section{〔参考 文 献〕}

1）斎藤，ほか：信学技報, SE 77-32, pp. 79-86, (1977).

2) J. E. Williams: Electro' 77, No. 12-3, (1977).

3) 武蔵野電気通信研究所, 通研ニュース No. 194, (1978).

4) 同上, No. 196, (1978).

5) 都築，ほか：昭53 信学総全大論文集，分 冊 1, No. 237.

6) 山本, ほか: 同上, No. 238.

7) 山口, ほか：同上, No. 248.

8）斎藤，ほか：信学技報， CPM 77-71, pp. 4552, (1977).

9) 坪谷, ほか：日経エレクトロニクス, No.1017, pp. 92-112, (1977).

10）日経エレクトロニクス，No. 6-12, pp. 187191, (1978). 